\title{
破裂性腹部大動脈瘤手術症例の検討
}

\author{
野 島 武 久* 麻 柄 達夫 尾上雅 彦 安 田 隆三郎**
}

\begin{abstract}
破裂性腹部大動脈瘤 19 例を対象とし手術成績を検討した。男性 18 例女性 1 例，平均年歯令は 69.2 歳 で, 70 歳以上の高齢者を 9 例含んでいた。 19 例中 15 例（79\%）でショックを呈しており，4 例に心 臓マッサージを要した。術中心停止で 1 例, 術後多臓器不全, 呼吸不全等で 3 例を失ったが, 残りの 15 例は軽快退院し死亡率は $21 \%$ であった。術後血液透析ないし持続血液濾過透析を 4 例, 再開腹止 血術を 2 例, 創し開での再閉腹術を 1 例, 術中イレウスチューブ留置を 3 例に行った。平均瘤径 82 $\mathrm{mm}$, 平均手術時間は 251 分, 平均総出血量は $5,139 \mathrm{ml}$, 平均同種血輸血量は $3,683 \mathrm{ml}$ を要した。 術 後平均挿管期間は 6.4 日, 平均禁食期間は 7.6 日であった。手術死亡 4 例中 3 例が 70 歳以上の高齢 者で, 死亡率は 70 歳未満群 $(10 \%)$ と比較して 70 歳以上群 $(33 \%)$ が有意に高值であった。高齢者 の破裂症例でも迅速な対応によって救命が可能で, 積極的な手術が必要と考えられた。 今後手術成績 の向上にはとくに高齢者における術後多藏器不全の克服が重要であると考えられ, 術中のイレウスチ ユーブ留置や持続血液濾過透析は年の一助になるものと考えている. 日心外会誌 27 巻 3 号 : 133-137 (1998)
\end{abstract}

Keywords：破裂性腹部大動脈瘤, 高齢者, 多臓器不全, イレウスチューブ, 持続血液滤過透析

\section{Surgical Treatment for Ruptured Abdominal Aortic Aneurysms}

Takehisa Nojima*, Tatsuo Magara, Masahiko Onoe and Ryuzaburo Yasuda** (Department of Cardiovascular Surgery, Shiga Seijinbyo Medical Center, Moriyama, Shiga, Japan and Yasuda Clinic*, Moriyama, Shiga, Japan)

From May 1981 through April 1996, 19 patients with ruptured abdominal aortic aneurysm were admitted to our department. There were 18 men and 1 woman with a mean age of 69 years. Fifteen cases were in shock with a systolic blood pressure $<80 \mathrm{mmHg}$ and 4 cases required chest compression for hypotension. One patient died of cardiac arrest on the operating table, 3 died of multiple organ failure or respiratory failure in hospital. The overall mortality rate was $21 \%$. The mortality rate of patients under the age of 70 years was $10 \%$, whereas that for those over 70 years of age was $33 \%$. We believe that the use of intraoperative ileal tubing and postoperative continuous hemofiltration would improve the mortality rate in cases of ruptured abdominal aortic aneurysms. Jpn. J. Cardiovasc. Surg. 27 : 133-137 (1998)

待期的腹部大動脈瘤に対する手術成績は安定し 安全に行えるようになったが，破裂性腹部大動脈 瘤に対する手術成績は極めて不良で，依然満足で きるものではない.なかでも高齢者破裂性腹部大 動脈瘤に対する手術成績は極めて悪く，耐術症例 であったにもかかわらず術後合併症で失うことも しばしば経験される。今回われわれは当科におけ る破裂性腹部大動脈瘤手術症例における手術成績 を検討したので報告する。

1997 年 5 月 29 日受付， 1997 年 9 月 8 日採用

滋賀県立成人病センター心臟血管外科 T 524-0022 守山市 守山 5-4-30

$*$ 現 浜松労災病院心臟血管外科

**安田医院

\section{対象と方法}

1981 年より 1996 年 4 月までに当科で経験した 腹部大動脈瘤手術症例は 138 例で，このうちの破 裂性腹部大動脈瘤症例 19 例を対象とした。瘤に 基づく痛みなどの症状を有しながらも明らかは破 裂が存在しない，いわゆる切迫破裂症例が 2 例あ ったがこれは対象から除外した。男性 18 例女性 1 例で, 平均年齢は 69.2 歳であり, 70 歳以上の 高齢者は 8 例, 80 歳以上が 1 例であった。瘤形 態は全例 infrarenal type で, Fitzgerald 分類で はII 型が 2 例，III型が 15 例，IV型が 2 例であっ た. 対象症例を 70 歳末満群 $(n=10), 70$ 歳以上 
群 $(n=9)$ の 2 群に分け, 手術死亡率, 大動脈瘤 径, 発症から手術までの時間, 手術時間, 出血 量, 同種血輸血量, 術後挿管期間, 術後禁食期 間，入院期間を検討した。 1991 年以降の 8 例で 術中自己血回収輸血装置であるセルセイバーを用 いた。手術方法は, 全例腹部正中切開, 経腹膜到 達法で行った。1 例で左開胸下に胸部大動脈遮断 した以外は腎動脈末梢の腹部大動脈を遮断し，Y または I 字型人工血管を用いた血行再建を行っ た。下腸間膜動脈は, 開存, 閉塞にかかわらず全 例結禁した。統計学的有意差検定は, MannWhitney test を用いて $p<0.05$ をもて有意差と し, 数值は平均 $\pm \mathrm{SD}$ で表した。

\section{結 果}

\section{1. 手術成績}

19 例中 15 例 $(79 \%$ ）で術前血圧 $80 \mathrm{mmHg}$ 以 下の出血性ショックを呈しており，4例に心臓マ ッサージを要した，術中心停止をきたし，試験開 腹に終わった症例が 1 例, 術後 8，28，52 日目に それぞれ多臓器不全, 呼吸不全等にて失った症例 が計 3 例あったが，他の 15 例は軽快退院でき手 術死亡率は $21 \%$ であった. 術後血液透析ないし は持続血液濾過透析を 4 例，再開腹止血術を 2 例, 創し開に対して再閉腹術を 1 例, 術中イレウ スチューブ留置を 3 例にそれぞれ施行した。大動 脈瘤直径は平均 $82 \mathrm{~mm}$, 発症から手術までの平 均時間は 17.5 時間，平均手術時間は 251 分，平 均術中総出血量は $5,139 \mathrm{ml}$, 平均同種血輸血量 は $3,683 \mathrm{ml}$ を要した。術後平均挿管期間は 6.4
日，平均禁食期間は 7.6 日であった（表 1).

\section{2. 高齢者破裂性腹部大動脈瘤手術症例}

対象の 19 例中 70 歳以上を高齢者として検討し た。症例は 70 歳から 80 歳までの 9 例でうち女性 1 例を含み, Fitzgerald 分類ではIII型が 8 例, IV 型が 1 例であった. $80 \mathrm{mmHg}$ 末満の血圧をショ ックとすると, 術前ショック症例は 9 例中 8 例に 認められた。瘤径は $60 \mathrm{~mm}$ から $110 \mathrm{~mm}$ で平均 $82 \mathrm{~mm}$ であった(表 2).

\section{70 歳未満群と 70 歳以上群の比較}

手術死亡 4 例中台上死の 1 例を含む 3 例が 70 歳以上の高齢者で, 死亡率では70歳未満群 （10\%）と比較して 70 歳以上群（33\%）が有意に

表 1 当科における破裂性腹部大動脈瘤の手術成績

破裂性腹部大動脈瘤手術症例 19 例

1 例：試験開腹術

18 例：人工血管置換術を施行

(Bifurcated 16, Tube graft 2)

$\begin{array}{lrl}\text { 手術時間 } & 254 \text { 分 } & (180 \sim 342 \text { 分 }) \\ \text { 出血量 } & 5139 \mathrm{ml} & (1841 \sim 11500 \mathrm{ml}) \\ \text { 輸液量 } & 4662 \mathrm{ml} & (1500 \sim 8000 \mathrm{ml}) \\ \text { 同種血輸血量 } & 3683 \mathrm{ml} & (2000 \sim 7800 \mathrm{ml}) \\ \text { 自己血輸血量 } & 1129 \mathrm{ml} & (600 \sim 2180 \mathrm{ml})\end{array}$

3 例：病院死亡

15 例：軽快退院

再開腹止血術：2 例, 再閉腹術： 1 例,

術後血液透析 $: 4$ 例

挿管期間 6.4 日（2～19 日）

禁食期間 7.6 日 $(4 \sim 26$ 日)

術中イレウスチューブ留置：3 例

表 270 歳以上高齢者

\begin{tabular}{cccccrc}
\hline 症例 & 年齢 & 性別 & Fitzgerald 分類 & 術前ショック & 瘤径 $(\mathrm{mm})$ & 転帰 \\
\hline 1) & 71 & 男性 & III & + & 90 & 生存 \\
$2 ｝ &{73} &{\text { 男性 }} &{\text { III }} &{+} &{90} &{\text { 生存 }} \\
{3 ｝ &{74} &{\text { 女性 }} &{\text { III }} &{-} &{100} &{\text { 生存 }} \\
{4)} &{74} &{\text { 男性 }} &{\text { III }} &{+} &{80} &{\text { 死亡 }} \\
{5)} &{76} &{\text { 男性 }} &{\text { IV }} &{+} &{60} &{\text { 生存 }} \\
{6)} &{76} &{\text { 男性 }} &{\text { III }} &{+} &{80} &{\text { 生存 }} \\
{7)} &{77} &{\text { 男性 }} &{\text { III }} &{+} &{110} &{\text { 生存 }} \\
{8 ｝ &{78} &{\text { 男性 }} &{\text { III }} &{+} &{60} &{\text { 死亡 }} \\
{9 ｝ &{80} &{\text { 男性 }} &{\text { III }} &{+} &{80} &{\text { 死亡 }} \\
{\hline}\end{array}$
\end{tabular}


表 32 群間比較

\begin{tabular}{lccc}
\hline & 70 歳末満群 & 70 歳以上群 & Statistics \\
\hline 症例数 & 10 & 9 & \\
死亡率 & $1(10 \%)$ & $3(33 \%)$ & $p<0.05$ \\
年齢 & 63.6 & 75.4 & - \\
瘤径 $(\mathrm{mm})$ & $81 \pm 12$ & $82 \pm 17$ & N.S. \\
発症から手術ま & $13 \pm 16$ & $21 \pm 13$ & N.S. \\
での時間 & & & \\
手術時間 $(\mathrm{min})$ & $241+43$ & $263 \pm 52$ & N.S. \\
出血量 $(\mathrm{ml})$ & $5147 \pm 2202$ & $5103 \pm 3503$ & N.S. \\
輸血量 $(\mathrm{ml})$ & $3488 \pm 1054$ & $3571 \pm 2089$ & N.S. \\
挿管日数 & $5.2 \pm 6.9$ & $6.8 \pm 6.6$ & N.S. \\
禁食期間 & $7.3 \pm 7.4$ & $8.0 \pm 2.5$ & N.S. \\
入院期間 & $43.7 \pm 18$ & $33.0 \pm 12$ & N.S. \\
\hline
\end{tabular}

mean \pm S.D.

高值であった. 70 歳未満群と 70 歳以上群の 2 群 の比較では, 瘤径, 発症から手術までの時間, 手 術時間, 術中総出血量, 輸血量, 挿管期間, 禁食 期間，入院期間には差を認めなかった（表 3).

\section{4. 死亡症例の検討}

死亡症例 4 例の原因はそれぞれ 1）74 歳男性, 術中に心停止となり心肺蘇生が功を奏さず台上 死，2）66 歳男性，呼吸不全で長期呼吸管理とな りMRSA 肺炎, 多臟器不全で術後 52 日目に死 亡，3）80 歳男性, 呼吸不全, 腎不全, 脳出血か ら多臟器不全となり術後 28 日目に死亡，4） 76 歳男性, 術後イレウスを契機として多臓器不全で 術後 8 日目に死亡，等であった。症例 4 では，腸 管内容の貯留と腸管, 腸間膜の浮腫から閉腹が極 めて困難であったことを経験したため, 以後の破 裂症例では術中腸管内容の吸引と術後のイレウス 防止を目的に，全例にイレウスチューブの留置を 行い現在に至っている。

\section{考察}

破裂性腹部大動脈瘤の手術成績には，術前の全 身状態と手術による迅速な止血と血行再建が寄与 することは論を待たない。しかし耐術症例におい ても, 術後合併症から死亡に至る症例があり, と くに高齢者においては慎重な術後管理が要求され る.

報告されている腹部大動脈瘤の手術成績は, 待
期的腹部大動脈瘤においては $1.4 \sim 8 \%{ }^{1 \sim 3)}$ であ り, 破裂性腹部大動脈瘤では $23 \sim 70 \%{ }^{4 \sim 7)}$ と報告 されている.さらに高歯者破裂症例に対する検討 では， 70 歳未満では $50 \%$ であるものが 70 歳以上 では $70 \%$ と有意に死亡率が高值となったとの報 告 ${ }^{8)}$ がある一方, 本邦での報告で 80 歳以上の破 裂性腹部大動脈瘤 5 例中 4 例を救命した報告9) も なされている．今回のわれわれの検討では，破裂 症例全体の死亡率 $21 \%$ は同時期の当科での待期 的腹部大動脈瘤手術症例 136 例中, 死亡が 2 例で $1.5 \%$ であることと比較すると極めて不良であっ たが, 報告されている破裂例の手術成績からは比 較的良好な成績と考えられた。70歳以上の高歯 者に限ると 9 例中 3 例 $(33 \%)$ が死亡し， 70 歳 未満の 10 例中 1 例 $(10 \%)$ と比較して有意差を もって成績は不良であった。

一般に待機的手術では 80 歳以上でも $3 \%$ 程度 の死亡率で若年者の $2 \%$ と比較して有意差がない との報告 ${ }^{10)}$ があるが，一般的には破裂症例では 年齢が大きなリスクファクターとされている11. これには高齢者における合併疾患の頻度が高く, 総じて藏器予備能が低下しているためとされる。 自験例においても高齢者破裂症例での瘤径, 発症 から手術までの時間などの術前因子，手術時間， 出血量, 輸血量などの術中因子, また挿管期間, 禁食期間などには統計的には差がなく，主な死亡 原因は多蔵器不全によるものであった。

破裂性腹部大動脈瘤のようなハイリスク症例で の手術成績を論じる場合, 手術適応とならんで術 前の患者選択すなわち selection bias が手術成績 に与える影響が問題となる ${ }^{12)}$. 当科では現在ま で，破裂性腹部大動脈瘤は患者選択を行わず全例 手術を行ってきた。これまで到着時死亡ないしは 到着時心肺停止症例等の経験はないが，術前，術 中に心臓マッサージを要した重篤な循環虚脱症例 を 4 例に認め，うち 2 例 $(50 \%)$ が軽快退院して いる．周術期に心停止を合併した場合はほとんど 救命できないとした報告が多い7). しかしわれわ れの経験からは重篤な循環虚脱症例であっても心 蔵マッサージを含む循環改善により救命できるこ とがあり，積極的な蘇生が必要と考えている。よ って現時点での当科における破裂性腹部大動脈瘤 
症例は年齢, 術前状態にかかわらず全症例を手術 適応としている。

手術手技であるが, Fitzgerald III型の 1 例で 術中の剥離操作で瘤が破裂し, 出血の制御を目的 に左開胸を行った症例を除き全例腎動脈末梢での 腹部大動脈遮断を行っている。バルンによる中枢 側血流遮断は, バルン挿入に必要な人員確保が困 難でかつ手術開始までの時間ないしは大動脈遮断 までの時間を延長させる可能性があり行っていな い.

当科に打ける死亡症例は 1 例の術中死以外は 4 例中 3 例が術後合併症での死亡であり，この術後 合併症の克服が手術成績の向上に重要と考える. 当科における術後合併症の発生頻度では腎機能障 害が 6 例 $(32 \%)$ と最も多く，呼吸不全 5 例，多 臓器不全 5 例, 肝機能障害 4 例, イレウス 3 例で あった。このなかで腎不全症例では，6 例中 4 例 に血液透析ないしは持続血液濾過透析を施行し た。透析を要さなかった 2 例は救命可能であった が, 透析を行った 4 例は救命は 1 例にとどまっ た。これは腎不全が手術前のショック，大量輸血 を原因としているためにすでに他の臟器障害を高 率に併発していることが多く，腎不全そのものが 多臓器不全の一分症として発生しているためと思 われる。当科ではこれまで急性腎不全に対しては washout therapy を用い可及的に血液透析を回避 していたが, これは術後急性期では, 従来の血液 透析での循環動態の悪化, 抗凝固剤による出血傾 向などの不利益を考慮した結果であった。しか し，最近は尿量の減少がみられた時点で可及的に 術後早期から持続血液濾過透析を開始している. これは，持続血液濾過透析が血液透析に比較して 循環動態に与える影響が少なく，また抗凝固剤と して nafamostat mesilate を用いることにより出 血性合併症の低減が可能となったことによる。ま た持続血液濾過透析が従来の血液透析で目的とし ていた腎不全での水分管理，腎機能補助だけでは なく，使用する膜の特性から tumor necrosis factor (TNF), interleukin (IL) などの多臓器 不全形成に関与するサイトカインを除去し予後を 改善するという報告13)もある。これらを根拠と して, 持続血液濾過透析が多臟器不全発症症例で
の救命率を今後向上させる可能性があるものと期 待し積極的に行っている。

また術後イレウスから多藏器不全に至り失った 症例で, 腸管内容の貯留と腸管の浮腫から, 閉腹 が極めて困難であった経験をした，以後の破裂症 例では, 全例に術中イレウスチューブの留置を行 い, 術中腸管内容の吸引を行い減圧することによ り閉腹を容易とし,さらに術後イレウス防止を図 つている。破裂性腹部大動脈瘤術後では周術期の ショック, 腸間膜や後腹膜血腫の存在, 腸管動脈 への不完全血行再建などでの腸管虚血から腸管機 能不全がおきるとされるが, 虚血腸管では bacterial translocation を契機としてエンドトキシン, サイトカインなどが誘導され多臓器不全の一因と

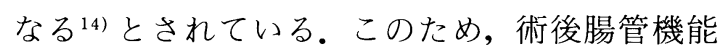
が改善するまでの間腸管内容を外部に排出するこ とはイレウスの防止だけでなく, bacterial translocation に伴う多藏器不全の防止となるものと考 えている。術中イレウスチューブ留置は容易であ り, 合併症は経験していない。一方, 腸管機能が 改善せず腸管壊死に至るとさらに救命は困難とな る。われわれはこれまで破裂症例では両側内腸骨 動脈血流の温存術式を選択し, 下行結腸, S 状結 腸の虚血性変化の有無を確認後閉腹しており, 結 果的に下腸間膜動脈を全例結禁することとなっ た。これまでわれわれは明らかな腸管壊死症例を 経験していないが, 術後イレウスで失った症例も 腸管壊死による腸管機能不全であった可能性は否 定できず，また破裂性腹部大動脈瘤術後では高頻 度に腸管壊死が生じると報告 ${ }^{15)}$ され, 今後手術 成績の向上には下腸間膜動脈の再建も考慮すべ き16)であると考えている。

\section{結語}

19 例の破裂性腹部大動脈瘤を経験し, うち 15 例を救命した．高齢者での腹部大動脈瘤破裂症例 でも迅速な対応によって救命が可能であり, 積極 的な手術が必要と考えられた．今後の手術成績の 向上にはとくに高齢者における術後多臓器不全の 克服が重要であり, 術中のイレウスチューブ留置 ならびに持続血液濾過透析はその一助になるもの と考えている. 


\section{文献}

1) Crawford, E. S., Saleh, S., Babb III, J. B. et al. : Infrarenal abdominal aortic aneurysm: Factors influencing survival after operation performed over a 25-year period. Ann. Surg. 193 : 699-709, 1981.

2）安藤太三，高本眞一，大北 裕ほか：合併症を有 する腹部大動脈溜に対する外科治療成績の検討. 日血外会誌 4：15-22, 1995.

3) Hollier, L. H., Taylor, L. M. and Ochsner, J. : Recommended indications for operative treatment of abdominal aortic aneurysms: Report of a subcommittee of the Joint Council of the Society for Vascular Surgery and the North American Chapter of the International Society for Cardiovascular Surgery. J. Vasc. Surg. 15 : 1046-1056, 1992.

4）櫻井 一, 村瀬允也, 前田正信ほか：破裂性腹部 大動脈瘤手術における左開胸併用法の検討. 日心 外会誌 26: 16-21, 1997.

5）森山由紀則, 豊平 均, 西元寺秀明ほか：破裂性 腹部大動脈瘤症例の検討一手術成績に関連の因 子と遠隔予後の検討一. 日心外会誌 $23: 186-190$, 1994.

6) Cappeller, W.A., Ramirez, H. and Kortman, H. : Abdominal aortic aneurysms: Risk factors and complications and their influence on indication for operation. J. Cardiovasc. Surg. 30: 572-578, 1989.

7) Johansen, K., Kohler, T. R., Nicholls, S. C. et al.: Ruptured abdominal aortic aneurysm:
The Harborview experience. J. Vasc. Surg 13 : 240-247, 1991.

8) Gaylis, H. and Kessler, E.: Ruptured aortic aneurysms. Surgery $87: 300-304,1980$.

9）山根正隆, 中山準平, 塩田邦彦ほか：80 歳以上腹 部大動脈瘤手術症例の検討. 日臨外医会誌 $\mathbf{5 7}$ : 1099-1102, 1996.

10) Paty, P. S. K., Lloyd, W. E., Chang, B. B. et al. : Aortic replacement for abdominal aortic aneurysm in elderly patients. Am. J. Surg. 166 : 191193, 1993.

11) Bernstein, E. F. and Chan, E. L.: Abdominal aortic aneurysm in high risk patients. Ann. Surg 200: 255-263, 1984.

12) Chalmers, R. T. A., Stonebridge, P. A., John, T. G. et al. : Abdominal aoritic aneurysm in the elderly. Br. J. Surg. 80 : 1122-1123, 1993.

13）松田兼一，平澤博之：持続血液濾過透析 (CHDF) を用いたSIRS の病態の調節と MOF の予防. 医学のあゆみ 181：113-117, 1997.

14) Deitch, E. A.: Multiple organ failure: Pathophysiology and potential future therapy. Ann. Surg. 216 : 117-134, 1992.

15) Welling, R. W., Roedersheimer, L. R., Arbaugh, J. J. et al. : Ischemic colitis following repair of ruptured abdominal aortic aneurysm. Arch. Surg. 120 : 1368-1370, 1985.

16）東上震一, 所 俊哉, 野口保蔵ほか: 破裂性腹部 大動脈溜術後の多臓器不全一とくに腸管壊死と の関連について一。 日心外会誌 $18: 877-880$, 1989. 